УДК 342.951

DOI https://doi.org/10.32844/2618-1258.2019.5-1.25

ГОНЧАРЕНКО Г.А.

\title{
ТЕОРЕТИКО-ПРАВОВІ ОСНОВИ ЗМІСТУ НАЦІОНАЛЬНОЇ БЕЗПЕКИ В КОНТЕКСТІ РОЗВИТКУ УПРАВЛІННЯ СЕКТОРА БЕЗПЕКИ
}

Статтю присвячено дослідженню теоретико-правових основ змісту національної безпеки в контексті розвитку управління сектора безпеки в рамках адміністративно-правового регулювання. Встановлено, що категорія «національна безпека» $\epsilon$ багатогранним, багатоаспектним, системним явищем. Запропоновано авторське поняття «безпека» і встановлено поняття «нація» в структурі категорії «національна безпека».

Здійснено аналіз наукових підходів змісту правової конструкції «національна безпека» із розподілом їх на шість груп. Досліджено становлення та розвиток терміна «національна безпека» на законодавчому рівні. Аргументовано, що національну безпеку варто розуміти як захищеність особистості, суспільства загалом та держави в усіх сферах їх життєдіяльності від загроз на запобігання, виявлення та відвернення загроз, які можуть позбавити матеріальних і духовних цінностей, зупинити або зменшити прогресивний сталий розвиток держави та суспільства.

Проаналізовано взаємозв'язок категорії «національна безпека» в контексті управління сектора безпеки. Визначено, що національна безпека забезпечується діяльністю уповноважених структур системи органів сектора безпеки і важливою у цьому забезпеченні $\epsilon$ регламентація на законодавчому рівні прийняття та реалізації управлінських рішень. Встановлено, що національна безпека $\epsilon$ ширшим поняттям, ніж сектор безпеки, а сектор безпеки, своєю чергою, $є$ підсистемою національної безпеки, суб'єкти сектора безпеки виконують мету, завдання та забезпечують інтереси національної безпеки.

Акцентовано на тому, що на систему суб'єктів сектора безпеки державою покладені завдання забезпечення національної безпеки, для чого необхідно: вдосконалювати механізми взаємодії між іiі суб' єктами, реформувати правові інститути недержавної системи іiі забезпечення, використовувати за бажанням громадян об'єднання у сфері забезпечення національної безпеки, а також запобігати, виявляти загрози та підтримувати напрями сталого розвитку держави та суспільства. Визнано, що вивчення національної безпеки як правової категорії науки $є$ пріоритетним у сучасному державотворенні України.

Ключові слова: правове регулювання, держава, поняття, ознаки, наукові коничепиії, загрози державі та суспільству, права і свободи людини і громадянина.

The article is devoted to the study of the theoretical and legal foundations of the content of national security in the context of the development of security sector management in the framework of administrative regulation. It is established that the category "national security" is a multifaceted, multidimensional, systemic phenomenon. The author's concept of "security" is proposed and the concept of "nation" is established in the structure of the category of "national security". A complete analysis of the scientific approaches to the content of the legal construction of "national security" with their distribution into six groups. The formation and development of the term "national security" at the legislative level is investigated. It is argued that national security should be understood as the protection of the individual, society as a whole and the state in all spheres of their life from threats to prevent, identify, prevent threats that can deprive of material and spiritual values, stop or reduce the progressive sustainable development of the state and society.

(C) ГОНЧАРЕНКО Г.А. - кандидат юридичних наук, доцент, доцент спеціальної кафедри № 1 «Правові засади державної безпеки» (Інститут підготовки юридичних кадрів для Служби безпеки України Національного юридичного університету імені Ярослава Мудрого) 
The relationship between the category of national security in the context of security sector governance is analyzed. It was determined that security is ensured by the activities of authorized structures of the system of security sector bodies, and important in this is the regulation at the legislative level of the adoption and implementation of management decisions. It has been established that security is a broader concept than the security sector, the security sector is a subsystem of national security, and security sector entities fulfill the goals, objectives and interests of national security and the like.

Attention is focused on the fact that the state has been entrusted with the system of security sector entities to ensure national security, namely, to improve the mechanisms of interaction between its entities, to reform the legal institutions of the non-governmental security system, to use, at the request of citizens, an association in the field of ensuring national security, as well as to prevent, identify threats and support the direction of sustainable development of the state and society. It is recognized that the study of national security as a legal category of science is a priority in modern state Ukraine.

Key words: legal regulation, state, concept, signs, scientific concepts, threats to the state and society, human and civil rights and freedoms.

Вступ. В умовах глобалізації Україна, як і кожна держава світу, тримає курс на економічну та правову незалежність. Зокрема, саме для досягнення цього результату важливим $є$ з'ясування теоретико-правових основ національної безпеки у сфері управління сектором безпеки, визначення ролі та місця національної безпеки в загальній системі механізмів управління системою органів сектора безпеки. У сьогоденні ми спостерігаємо тенденцію впливу загроз на діяльність держави, в майбутньому розвиток такої ситуації може привести до зниження рівня національної та державної безпеки України, ефективності управління сектором безпеки.

Проблематиці з'ясування сутності «національна безпека» в науковій літературі приділяли свою увагу такі науковці, як В.Б. Авер'янов, В.Я. Тацій, Н.М. Матюхіна, В.М. Гаращук, В.П. Горбулін, Ю.П. Битяк, В.А. Ліпкан, В.Г. Пилипчук, В.В. Крутов, В.П. Смельянов, О.М. Шевчук та ін. В Україні є значна кількість наукових праць, присвячених окремим питанням правового регулювання національної безпеки, 3'ясуванню його поняття та змісту. Однак в юридичній науці досі не здійснено досліджень, які б розглядали теоретико-правові основи розвитку сутності національної безпеки, пов'язані з управлінням сектором безпеки.

Постановка завдання. Метою статті $є$ здійснити правовий аналіз поняття «національна безпека», окремих елементів, визначити його складники, сферу застосування, окреслити сучасні наукові підходи, а також дослідити його ознаки та взаємозв'язок у системі управління сектора безпеки.

Результати дослідження. Проблема правового забезпечення інтересів особи, суспільства та держави від внутрішніх і зовнішніх загроз є актуальним питанням як в Україні, так і в світі. Реформування управління системою органів сектора безпеки є головним пріоритетом держави відповідно до Стратегії сталого розвитку «Україна - 2020» [1]. До ключових заходів реалізації вищевказаної реформи зараховано оновлення основних підходів до забезпечення національної безпеки держави. Крім того, метою Концепції розвитку сектора безпеки і оборони України $є$ створення національної системи реагування на кризові ситуації, своєчасне виявлення, запобігання та нейтралізацію зовнішніх і внутрішніх загроз національній безпеці, гарантування особистої безпеки, конституційних прав і свобод людини і громадянина, забезпечення кібербезпеки, оперативне спільне реагування на кризові та надзвичайні ситуації [2]

У процесі дослідження понятійних категорій в управлінні сектором безпеки найпоширенішим поняттям як в Україні, так у країнах-членах СС, СНД, НАТО є термін «національна безпека». У наукових джерелах немає єдиного поняття «національна безпека», також у нормативно-правових документах держав використовуються різні трактування цього терміна [3, с. 211-212]. Проблематика змісту національної безпеки має власні особливості, i, як справедливо зазначає С.В. Кортунов, кожен дослідник і соціум розуміють ії по-різному. Так, у вітчизняних теоретичних джерелах термін «національна безпека» з'явився в 1993 р. Приблизно з 1994 р. почалася розробка її теорії та методології на основі міждисциплінарного підходу [4, с. 22-23] . Варто погодитись із цією точкою зору авторів, бо дефініція «національна безпека» дійсно використовується в різних галузях: юридичній, економічній, математичній, військовій, політології, теорії міжнародних відносин, філософії, соціології до конфліктології та ін. [3, с. 84], у кожній 
сфері можуть бути різні аспекти визначення терміна «національна безпека». Соціологи, приміром, визначають «національну безпеку» як стан системи, що забезпечує суспільні відносини між суб'єктами соціуму, індивідами й інститутами держави як у межах діяльності як на рівні держави, так і на міжнародному рівні, що уможливлює повну реалізацію та захищеність життєво важливих інтересів суспільства від загроз внутрішнього та зовнішнього походження через досягнення необхідної збалансованості інтересів кожного з учасників відносин через їх оптимальне зіставлення з інтересами інших суб'єктів [5, с. $23 ; 6$, с. 5 ].

В Україні в правовий обіг поняття «національна безпека» було введено в 1993 р. Його визначення було наведене в Концепції (Основах державної політики) національної безпеки України [7], де зазначалося, що національна безпека є станом захищеності життєво важливих інтересів особи, суспільства та держави від внутрішніх і зовнішніх загроз, що $є$ необхідною умовою збереження та примноження духовних і матеріальних цінностей.

З часом досліджуваний термін було використано в положеннях Закону України «Про основи національної безпеки». Під цим поняттям розуміли захищеність життєво важливих інтересів людини і громадянина, суспільства і держави, що забезпечує сталий розвиток суспільства, своєчасне виявлення, попередження і нейтралізацію реальних та потенційних загроз національним інтересам [8]. У цей нормативно-правовий акт у 2017 р. було внесено зміни - додано перелік реальних та потенційних загроз, які визначались: «у сфері правоохоронної діяльності, боротьби з корупцією, прикордонної діяльності та оборони, міграційної політики, охорони здоров'я, охорони дитинства, освіти та науки, науково-технічної та інноваційної політики, культурного розвитку населення, забезпечення свободи слова та інформаційної безпеки, кібербезпеки та кіберзахисту» тощо.

Відповідно до чинної редакції у ст. 1 Закону України «Про національну безпеку» правова конструкція «національна безпека України» наведена як захищеність державного суверенітету, територіальної цілісності, демократичного конституційного ладу та інших національних інтересів України від реальних та потенційних загроз (п. 9) [9]. Отже, на законодавчому рівні еволюція поняття «національна безпека» визначається від стану захищеності життєво важливих інтересів особи, суспільства та держави від внутрішніх і зовнішніх загроз, а далі законодавець вказував на попередження і нейтралізацію реальних та потенційних загроз та навів їх перелік. Однак сучасне розуміння терміна «національна безпека України», з нашої точки зору, є більш прогресивним через те, що з розвитком суспільства можуть виникати нові загрози національній безпеці.

У подальшому варто розглянути складники категорії «національна безпека». Так, «національний» походить від слова «нація». У цьому дослідженні «націю» варто розуміти як суспільно-політичну категорію, що вказує на стосунки народу з певною державою і об'єднує в собі як певні елементи громадян цієї держави. Фактично у ст. 13 Конституції України визначено такий підхід. У положеннях цієї статті Основного Закону врегульовано: «Земля, іiі надра, атмосферне повітря, водні та інші ресурси, які знаходяться в межах території України, природні ресурси іiі континентального шельфу, виключної (морської) економічної зони є об’єктами права власності Українського народу. Від імені Українського народу права власника здійснюють органи державної влади та органи місцевого самоврядування в межах, визначених цією Конституцією» [10].

Отже, можна дійти висновку, що у правовій конструкції «національна безпека» термін «нація» варто розглядати як український народ, а саме: спільноту всіх громадян та осіб без громадянства, що нині проживають на території держави і підпадають під іiї юрисдикцію. Іншими словами, національна безпека - це безпека будь-якої особи (осіб), що проживає на території України.

Важливим є розкриття змісту поняття «безпека». Так, філософський словник термін «безпека» наводить як реально існуюче явище об'єктивної дійсності, тому що об'єктивна реальність «містить у собі різні матеріальні об'єкти, їх властивості, простір, час, рух, закони, різні суспільні явища - виробничі відносини, державу, культуру тощо» [11, с. 291]. Безпека як явище має поліфункціональний характер, де безпека як соціальна цінність суспільства - діяльність певної групи різних суб'єктів, а як соціальна потреба - це цілеспрямований результат такої діяльності. Причому безпека $є$ необхідною умовою існування особистості, суспільства і держави, що гарантує можливість подальшого прогресивного розвитку цих елементів [12, с. 121].

О.А. Делінський, досліджуючи питання безпеки, виділив чотири рівні (наукові підходи): 1) національна безпека (передбачає захист основних інтересів конкретної держави); 2) регіональна безпека (наявність найбільш ефективних систем безпеки в рамках конкретних географічних регіонів); 3) міжнародна безпека (взаємозв'язок безпеки однієї держави з безпекою інших держав (колективне використання збройної сили, міжнародні інститути і режими безпеки)); 4) глобальна безпека (всеосяжний характер, включає в себе військову безпеку, захист громадянських прав, 
навколишнього середовища, економічного розвитку тощо) [13, с. 594]. В.П. Циганов визначає термін «безпека» як діяльність людей, суспільства, держави, світового співтовариства народів щодо виявлення, запобігання, послаблення, відвернення загрози, здатної загубити їх, позбавити матеріальних і духовних цінностей, завдати невідшкодованих збитків, заблокувати шляхи для прогресивного розвитку [14, с. 32]. На сучасному етапі розвитку держави, як зазначається в наукових джерелах, поняття безпеки охоплює військові, економічні, технологічні, екологічні, соціальні та гуманітарні аспекти. До його сфери також входять питання збереження національної ідентичності та захист базових прав і свобод громадян [15, с. 8].

3 нашої точки зору, безпека - це правове явище, в якому діяльність людей, суспільства, держави, певної групи різних суб'єктів спрямована на запобігання, виявлення, відвернення загроз, які можуть позбавити матеріальних і духовних цінностей, зупинити або зменшити прогресивний сталий розвиток держави та суспільства.

Національна безпека України є багатогранним, багатоаспектним, системним явищем $[16$, c. 137], і треба його розглядати як сукупність взаємопов'язаних складників, різнорідних за функціональними сферами, які прямо закріплені в першому розділі Основного Закону. Серед них: екологічна (ст. 16), економічна (ч. 1 ст. 17), інформаційна (ч. 1 ст. 17) та державна безпека (ч. 3 ст. 17) [17, с. 4]. В.П. Горбулін та А.Б. Качинський під поняттям «національна безпека» розуміють захищеність життєво важливих інтересів особистості, суспільства й держави та довкілля в різних сферах життєдіяльності від внутрішніх та зовнішніх загроз, що забезпечує сталий і поступальний розвиток країни $[18$, с. 25$]$. Отже, національна безпека - це міра реального рівня прав і свобод членів людського співтовариства (громадян) відповідної цьому співтовариству держави $[15$, с. 33]. А.В. Возженнікова та Н.М. Герман під національною безпекою розуміють стан захищеності інтересів, що є життєво важливими для окремої особистості, суспільства загалом та держави у всіх сферах їх життєдіяльності від загроз і небезпек внутрішнього і зовнішнього походження, що, своєю чергою, підтримує стабільність їх розвитку [19, с 57.]. А.А. Кайгородцев розглядав національну безпеку як: 1) універсальну цінність, однаково актуальну і потрібну для окремого громадянина, соціальної групи, невеликої чи масштабної нації, з яких складається держава; 2) стан, шляхи розвитку й особливості життєдіяльності нації, що, своєю чергою, являє собою державно-територіальну спільність людей, які гарантують, незважаючи на присутність i негативний вплив деяких чинників, іiі виживання, а також існування і процвітання на вільних і незалежних засадах $[20$, с. 72$] .3$ нашої точки зору, національну безпеку варто розуміти як захищеність особистості, суспільства загалом та держави у всіх сферах їх життєдіяльності від загроз на запобігання, виявлення та відвернення загроз, які можуть позбавити матеріальних і духовних цінностей, зупинити або зменшити прогресивний сталий розвиток держави та суспільства.

Варто погодитись із думкою В.Г. Пилипчука, який вказує, що мета системи забезпечення національної безпеки України полягає в тому, щоб створити механізм, який дає змогу виробити державну і суспільну політику та стратегію держави у сфері забезпечення особистісної, суспільної та державної безпеки та реалізувати цю стратегію в конкретних функціях структур, об'єднаних у зазначену систему [21, с. 67-68]. Варто також нагадати законодавчу дефініцію: «національна безпека - як захищеність державного суверенітету, територіальної цілісності, демократичного конституційного ладу та інших національних інтересів України від реальних та потенційних загроз».

Стосовно взаємозв'язку національної безпеки з сектором безпеки, відповідно до ст. 1 Закону України «Про національну безпеку», наведено поняття «сектор безпеки і оборони», де передбачено, що діяльність органів сектора безпеки перебуває під демократичним цивільним контролем і відповідно до Конституції та законів України за функціональним призначенням спрямована на захист національних інтересів України від загроз (п. 16) [9]. Також у цьому документі врегульовано, що сили безпеки - це правоохоронні та розвідувальні органи, державні органи спеціального призначення з правоохоронними функціями, сили цивільного захисту та інші органи, на які Конституцією та законами України покладено функції із забезпечення національної безпеки України (п. 17) [9]. В юридичній літературі «сектор безпеки» розуміють як сукупність державних органів та організацій, які покликані гарантувати безпеку особи, суспільства та держави. До елементів сектора безпеки України зараховують особисту безпеку громадян, громадську безпеку, державну безпеку, військову безпеку [22, с. 9].

Отже, національна безпека забезпечується діяльністю уповноважених структур системи органів сектора безпеки. Важливою у цьому забезпеченні $є$ регламентація на законодавчому рівні прийняття та реалізації управлінських рішень. Національна безпека $є$ ширшим поняттям, 
ніж сектор безпеки. Сектор безпеки є підсистемою національної безпеки. Суб’єкти сектора безпеки виконують мету, завдання та інтереси національної безпеки тощо. На систему суб' єктів сектора безпеки покладені державою завдання забезпечення національної безпеки, для чого необхідно: вдосконалювати механізми взаємодії між ії суб'єктами, реформувати правові інститути недержавної системи ії забезпечення, використовувати за бажанням громадян об'єднання у сфері забезпечення національної безпеки, а також запобігати, виявляти загрози та підтримувати напрями сталого розвитку держави та суспільства.

В юридичній літературі є різні наукові підходи до з'ясування сутності категорії національної безпеки. О.В. Глазов виділяє три основні теоретичні наукові підходи в розумінні сутності національної безпеки. Перший - захист цінностей суспільства, серед яких виокремлюють основні, такі як політична незалежність, економічний добробут, розвиток, справедливість. Представниками, що поділяють такий підхід, є А. Волферс, Д. Гадді, Г. Даєм, Дж. Джонсон, Д. Кауфман, Р. Коен. Другий - забезпечення національної безпеки розглядалось у контексті захисту інтересів держави, а також захисту інтересів особи (громадянина) та суспільства. Науковцями, які підтримують цей напрям, є А. Бетлер, О. Данільян, О. Дзьобань, М. Каплан, М. Панов, та ін. Третій підхід - в основу покладено взаємозв'язок національних цінностей та інтересів, необхідності врахування їх взаємозумовленості в дослідженні проблем національної безпеки. Прихильниками цього можна назвати В. Горбуліна, Б. Демидова, А. Качинського, В. Ліпкана, Г. Ситника. Деякі дослідники зближують «національний інтерес» 3 «інтересом держави», розглядаючи державу як основний засіб вираження «національних інтересів». Прикладом може служити позиція, що національний інтерес виникає за наявності єдності інтересів суспільства і держави [23, с. 38-41; 24, с. 27; 25 , с. $47 ; 26]$. Ми не виключаємо інших підходів у частині розуміння концепції «державної» чи «національної» безпеки до концепції глобального рівня вирішення проблем усього людства $[27$, с. 75$]$. Основу глобальної безпеки мають становити національні безпеки держав, що забезпечують їх стабільний розвиток і не створюють загрози сусідам. Тільки такі держави можуть створювати колективні і регіональні системи безпеки [28, с. 80].

Інші дослідники ототожнюють «національні інтереси» 3 інтересами переважної в державі етнічної групи. Прихильником такого підходу є дослідник М.П. Вавринчук, який вважає, що інтересам нації відповідає включення до складу держави лише етнічно близьких народів $[29$, с. 145]. Також є точка зору, що суб'єктом «національних інтересів» $є$ громадянське суспільство, тобто шар незалежних від держави приватних власників, оскільки нинішня влада і фундаментальні інтереси українського народу несумісні [30].

Враховуючи вищевикладене, доцільно вказати, що науковими напрямами розуміння змісту національної безпеки є такі: 1) захист цінностей суспільства; 2) забезпечення національної безпеки розглядалось у контексті захисту інтересів держави, а також захисту інтересів особи (громадянина) та суспільства; 3) взаємозв'язок національних цінностей та інтересів, необхідності врахування їх взаємозумовленості в дослідженні проблем національної безпеки; 4) глобальної безпеки, коли в цю систему входять національні системи безпеки держав, що забезпечують їх стабільний розвиток і не створюють загрози сусідам; 5) «національні інтереси» пов'язані з інтересами переважної в державі етнічної групи; 6) суб'єктом «національних інтересів» $є$ громадянське суспільство, тобто шар незалежних від держави приватних власників, оскільки нинішня влада і фундаментальні інтереси українського народу несумісні тощо.

Висновки. Вивчення національної безпеки як правової категорії науки, є пріоритетним у сучасному державотворенні України. У дослідженні та з'ясуванні проблем правового забезпечення безпеки досить важливим $є$ науковий підхід, у рамках якого можна здійснити тлумачення «національної безпеки» як наукової категорії на основі еволюційного підходу, інтерпретації його наукового знання. Виникнення категорії національної безпеки починається із формуванням держави, становленням національних інтересів, виникненням та подоланням загроз і пов'язане 3 діяльністю та розвитком системи сектора безпеки. Національна безпека $є$ ширшим поняттям, ніж сектор безпеки. Сектор безпеки є підсистемою національної безпеки. Суб'єкти сектора безпеки виконують та забезпечують мету, завдання та інтереси національної безпеки. Важливою у цьому правовому забезпеченні є регламентація на законодавчому рівні прийняття та реалізації управлінських рішень.

\section{Список використаних джерел:}

1. Про Стратегію сталого розвитку «Україна - 2020»: Указ Президента України від 12.01.2015 р. № 5/2015. Офіційний вісник Президента України. 2015. № 2. С. 14. Ст. 154. 
2. Про рішення Ради національної безпеки і оборони України від 4 березня 2016 р. «Про Концепцію розвитку сектора безпеки і оборони України» : Указ Президента України № 92/2016. URL: https://zakon.rada.gov.ua/laws/show/92/2016\#n2.

3. Новицький Г.В. Теоретико-правові основи забезпечення національної безпеки України: моногр. Київ : Інтертехнологія, 2008. 496 с.

4. Кортунов С.В. Концептуальные основы национальной и международной безопасности : учеб.-метод. пособие. Москва : Госуд. ун-т: Высшая Школа Экономики, 2007. 308 с.

5. Воронкова В.Г. Соціально-орієнтоване державне управління : монографія / В.Г. Воронкова, О.О. Фурсін, Н.В. Сапа ; під ред. В.Г. Воронкової. Запоріжжя : Вид-во ЗДІА, 2011. 256 с.

6. Снігова О.Ю. Механізм державного та регіонального управління соціальною безпекою : автореф. дис. ... канд. екон. н. : 08.02.03 / НАН України; Ін-т екон. промислов. Донецьк, 2006. $20 \mathrm{c}$.

7. Про національну безпеку : Закон України від 21.06.2018 p. № 2469-VIII. Вiдомості Верховної Ради (ВВР). 2018. № 31. Ст. 241.

8. Про основи національної безпеки України : Закон України. Офіщійний вісник України. 2003. № 29. Ст. 1433 (втратив чинність).

9. Про національну безпеку : Закон України від 21.06.2018 p. № 2469-VIII. Bidомості Bepховної Ради (ВВР). 2018. № 31. Ст. 241.

10. Конституція України : Закон України від 28.06.1996 р. Відомості Верховної Ради України. 1996. № 30. Ст. 141.

11. Философский словарь/подред. М.М.Розенталя. 3-еизд. Москва:Политиздат, $1972.496 \mathrm{c}$.

12. Чуваков А.О. Безпека: соціально-політична сутність поняття. Правова держава. 2014. № 18. C. 119-123.

13. Делінський О.А. Концептуальні аспекти становлення сучасної системи міжнародної безпеки. Актуальні проблеми держави та права. 2001. Вип. 11. С. 593-598.

14. Циганов В.В. Національна безпека України : посібник. Національна академія внутрішніх справ України. Київ, 2004. 100 с.

15. Дацків Р.М. Економічна безпека держави в умовах глобальної конкуренції. Львів : Центр Європи, 2006. 160 с.

16. Чуйко 3.Д. Питання конституційних засад національної безпеки в Україні. Вісник Акад. правових наук Украӥни. 2008. № 3 (54). С. 137-139.

17. Чуйко 3.Д. Конституційні основи національної безпеки України : автореф. дис. ... канд. юрид. наук : 12.00.02; ХНЮА ім. Ярослава Мудрого. Харків, 2008. 18 с.

18. Горбулін В.П. Системно-концептуальні засади стратегії національної безпеки України : моногр. / В.П. Горбулін, А.Б. Качинський. Київ : «НВЦ Євроатлантікінформ», 2007. 592 с.

19. Возжеников А.В. Национальная безопасность России: вызовы, опасности и угрозы : вопросы теории и практики / А.В. Возжеников, И.Н. Герман. Москва : Дело, 2015. 206 с.

20. Кайгородцев А.А. Механизм экономической безопасности Казахстана. Наука и современность. 2016. \# 1(7). С. 69-77.

21. Пилипчук В.Г. Система і компетенція державних органів зі спеціальним статусом у сфері національної безпеки України : монографія / В.Г. Пилипчук, О.П. Дзьобань, В.Я. Настюк. Харків : Право, 2009. 200 с.

22. Чорний В.С. Особливості демократичного цивільного контролю над військовою сферою українського суспільства на сучасному етапі. Social development \& Security. 2018. № 3 (5). C. 3-13. URL: http://paperssds.eu/index.php/JSPSDS/article/view/41/38.

23. Ситник Г.П. Державне управління у сфері національної безпеки (концептуальні та організаційно-правові засади). Київ : НАДУ, 2011. 730 с.

24. Теоретико-методологічні засади забезпечення національної безпеки держави у іiі визначальних сферах : моногр. / [В.Ю. Богданович, А.І. Семенченко, Ю.В. Сгоров, О.О. Бортник]. Київ : Видавництво Кий, 2007. 370 с.

25. Ліпкан В.А. Теорія національної безпеки : підручник. Київ : КНТ, 2009. 631 с.

26. Глазов О.В. Національна безпека: сутність, ознаки, концепція та геополітичні чинники. Наукові праиі. Політологія. 2011. Вип. 143. Т. 155. С. 42- 45. URL: politics.chdu.edu.ua

27. Корж І.Ф. Державна безпека: методологічні підходи до системи складових поняття. Правова інформатика. 2012. № 4(36). С. 69-75.

28. Кузьменко А. Проблеми відповідності стратегії та системи забезпечення безпеки України національним потребам. Юридичний журнал. 2006. № 10. С. 79-87. 
29. Вавринчук М.П. Етнополітичная безпека в системі національної безпеки України на етапі сучасного державотворення. Київ : Правова єдність, 2009. 288 с.

30. Хачатурян Х.В. Переорієнтація державного управління на потреби громадян: нова європейська модель та Україна. Вісник Київського міжнародного університету. Серія: Міжнародні відносини. 2009. № 8. URL: http://www.kymu.edu.ua/vmv/v/08/khachaturian.htm.

УДК 342.9

DOI https://doi.org/10.32844/2618-1258.2019.5-1.26

ДЕГТЯРЬОВА С.В.

\section{ПОНЯТТЯ ТА СУТНІСТЬ ПРАВОВОГО СТАТУСУ СУБ'ЄКТІВ ДЕРЖАВНОГО РЕГУЛЮВАННЯ В АГРОПРОМИСЛОВІЙ СФЕРІ}

У статті на основі аналізу наукових поглядів учених надано авторське визначення поняття правового статусу суб'єктів державного регулювання в агропромисловій сфері. Обгрунтовано, що правовий статус суб'єктів державного регулювання в агропромисловій сфері є складною збірною категорією, яка включає у себе цілу низку елементів, що пов'язані між собою, доповнюють один одного та у сукупності відображають, яке місце посідає той чи інший суб'єкт у відповідній системі. 3'ясовано, що соціальний статус відображає положення особи в суспільстві, своєю чергою, правовий статус його конкретизує та є об' єктивним показником положення суб'єкта у конкретних правовідносинах. В юридичній літературі сформовано чималу кількість підходів до визначення поняття «правовий статус». Наголошено на важливості правового статусу, а саме політичні та юридичні гарантії забезпечення правового статусу суб'єктів державного регулювання агропромислової сфери. Зокрема, політичні гарантії слід розуміти як сукупність визначених законом умов, засобів, інструментів та способів, які спрямовуються на забезпечення ефективної роботи уповноважених суб'єктів у досліджуваній сфері. Уважаємо, що політичні гарантії надають їхній діяльності більшої цілеспрямованості, визначають конкретний вектор для подальшої роботи органів державної влади у цій сфері. Що ж стосується юридичних гарантій, то їх найбільш важливе призначення полягає у тому, що держава повинна створити необхідне правове поле, надати їм усі необхідні права, обов'язки та повноваження для того, щоб окреслені вище суб'єкти могли якісно й ефективно вирішувати завдання, які стоять перед ними, та виконувати свої функції. Визначено, що під правовим статусом суб'єктів державного регулювання в агропромисловій сфері необхідно розуміти сукупність суб'єктивних прав, юридичних обов'язків тощо, які закріплені нормами чинного законодавства України та визначають положення уповноваженого суб'єкта у відповідній системі. Відзначено, що правовий статус не лише охоплює багато аспектів, які характеризують відповідний суб'єкт, він ще й складається з великої кількості елементів, аналіз яких, своєю чергою, надасть більш об'єктивну картину щодо сутності, змісту та призначення окреслених у роботі суб'єктів.

Ключові слова: статус, соиіальний статус, правовий статус, суб'єкт, державне регулювання, агропромислова сфера.

In the article, based on the analysis of scientific views of scientists, the author defines the concept of legal status of the subjects of state regulation in the agro-industrial sphere. It is substantiated that the legal status of the subjects of state regulation in the agro-industrial sphere is a complex assembly category that includes a number of elements that are

(C) ДЕГТЯРЬОВА С.В. - кандидат юридичних наук, докторант (Харківський національний університет внутрішніх справ) 